\title{
Evaluation of removal efficiency of heavy metals by low-cost activated carbon prepared from African palm fruit
}

\author{
Sani Abdulrazak ${ }^{1} \cdot$ K. Hussaini ${ }^{2} \cdot$ H. M. Sani ${ }^{3}$
}

Received: 29 January 2016/ Accepted: 31 August 2016/Published online: 12 September 2016

(C) The Author(s) 2016. This article is published with open access at Springerlink.com

\begin{abstract}
This study details the removal of heavy metals; Cadmium, Copper, Nickel, and Lead from wastewater effluent using an activated carbon produced from African palm fruit. The effluent was obtained from Old Panteka market; a metal scrap Market located in Kaduna State, Nigeria, which has several components that constitute high level of pollution in the environment. The effect of temperature and contact time on the removal of these heavy metals using the activated carbon produced was investigated. The activated carbon showed a significant ability in removing heavy metals; Cadmium, Copper, Nickel, and Lead from the wastewater. Higher percentage removal was observed at a temperature of $80{ }^{\circ} \mathrm{C}(93.23 \pm 0.035$, $96.71 \pm 0.097,92.01 \pm 0.018$, and $95.42 \pm 0.067 \%$ for Cadmium, Copper, Nickel, and Lead, respectively) and at an optimum contact time of $60 \mathrm{~min}(99.235 \pm 0.148$, $96.711 \pm 0.083,95.34 \pm 0.015$, and $97.750 \pm 0.166 \%$ for Cadmium, Copper, Nickel, and Lead, respectively) after which the percentage removal decreases. This work, therefore, suggests that African palm fruit can be successfully applied to solve this environmental pollution.
\end{abstract}

Keywords African palm fruit . Wastewater effluent . Adsorption · Temperature $\cdot$ Contact time $\cdot$ Activated carbon $\cdot$ Heavy metals

Sani Abdulrazak

sazzak175@gmail.com

1 Department of Veterinary Physiology, Faculty of Veterinary Medicine, Ahmadu Bello University, Zaria, Nigeria

2 Department of Chemistry, Faculty of Science, Federal University of Technology, Minna, Nigeria

3 Department of Microbiology, Faculty of Science, Ahmadu Bello University, Zaria, Nigeria

\section{Introduction}

Heavy metal is any metallic chemical element that is poisonous at low concentrations (Srivastava and Goyal 2010) when consumed over permissible quantities cause psychological disorder (Prabakarani et al. 2011). They are highly toxic for both animals and human beings (Nwankwo and Elinder 1979; Jarup 2003), and can be bio-accumulated through biological chains and are non biodegradable and persistent (Haware and Pramod 2011). Their toxicity may occur due to industrial emission that contaminates waterways, nearby streams and rivers, contamination of irrigation water, the application of fertilizer and metal-based pesticides, harvesting process, transportation, storage, or sale. (Bempah et al. 2011). This contamination is a widespread environmental problem (Nwankwo and Elinder 1979; Jarup 2003). The harmful effects caused by heavy metals in water to living organism if excess amount is ingested through food (El-Said et al. 2010). Elements, such as Cadmium and Chromium, are considered carcinogenic, while Iron, Copper, Manganese, Zinc, and Nickel are considered essential trace elements (Sulyman et al. 2015). Painting paper, pigment, fuels, photographic materials electroplating, battery manufactures, explosive manufacturing, and metal working industries discharge a large amount of heavy metals, including Copper, Zinc, Lead, and Nickel ions in water bodies which cause serious environmental contamination (Gupta et al. 2004).

Activated carbon is a term for a family of highly carbonaceous materials none of which can be characterized by a structural formula. It is an amorphous solid consisting of micro crystallites with a graphite lattice, and they are non polar, highly porous, usually prepared in small pellets or a powder. The limitation is that it reacts with oxygen at moderate temperatures (over $300{ }^{\circ} \mathrm{C}$ ). It is obtained from

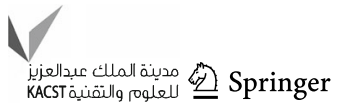


carbonaceous material; carbonization and activation are the two phases of manufacturing activated carbon (Verla et al. 2012; Nwabanne and Igbokwe 2012). Waste water is any water that has been adversely affected in quality by anthropogenic influence and can originate from a combination of domestic, industrial, commercial, or agricultural activities, surface runoff, or storm water, and from sewer inflow or infiltration (WHO 2006).

Wong et al. (2003) using tartaric acid modified rice husk as adsorbent have carried out batch studies for the removal of lead and copper and reported the effects of various parameters, such as $\mathrm{pH}$, initial concentration of adsorbate, particle size, and temperature. It was reported that modified rice husk is a potentially useful material for the removal of Copper and Lead from aqueous solutions. The rapid uptake and high adsorption capacity make it a very attractive alternative for adsorption. It was also shown that the uptake of Copper and Lead was higher when $\mathrm{pH}$ was increased from 2 to 3, thereafter remained relatively constant. Mohan and Singh (2002) carried out research on single- and multi-component adsorption of cadmium and zinc using activated carbon derived from sugarcane baggasse. They reported that the removal of Cadmium and Zinc is found to increase as $\mathrm{pH}$ increases above 2 and at $\mathrm{pH}>8.0$ the uptake is $100 \%$. It is also evident that the sorption affinity of the derived activated carbon towards Cadmium and Zinc is better than other available adsorbents. Selvi et al. (2001) studied the removal of Chromium from aqueous solution by adsorption onto activated carbon prepared from coconut tree sawdust for the removal of chromuim from aqueous solution. Batch mode adsorption studies were carried out by varying agitation time, initial Chromium concentration, carbon concentration, and $\mathrm{pH}$. Langmuir and Freundlich adsorption isotherms were applied to model the adsorption data. Adsorption capacity was calculated from the Langmuir isotherm and was $3.46 \mathrm{mg} / \mathrm{g}$ at the initial $\mathrm{pH}$ of 3.0 for particle size 125-250 $\mu \mathrm{m}$. The adsorption of Chromium was $\mathrm{pH}$ dependent, and maximum removal was observed in the acidic $\mathrm{pH}$ range.

The need for safe and economical methods for the removal of heavy metals from waste water has necessitated research low-cost agricultural waste by-products, such as sugarcane bagasse (Kadirvelu et al. 2001), rice husk (Srinivasan et al. 1998), sawdust (Ajmal et al. 1996), coconut husk (Tan et al. 1993), oil palm shell (Khan et al. 2003), and Moringa oleifera pod (Abdulrazak et al. 2015), for the removal of heavy metals from waste water, have been investigated by various researchers. Cost is an important parameter for comparing the adsorbent materials. However, cost information is seldom reported, and the expense of individual adsorbents varies depending on the degree of processing required and its availability. Due to their toxicity, heavy metal exposure causes various health hazards, persistency, and non-biodegradability. There is need for continuous research on readily available low-cost adsorbent for the removal of these toxic metals from waste water. Borassus aethiopum shell have little economic value, hence the importance of this work.

The conventional methods for heavy metal removal from waste water which includes chemical precipitation, reverse osmosis, and solvent extraction are expensive especially for a developing country, such as Nigeria. Adsorption is an alternative method, because it is cost effective and simple to design.

The objectives of this work are aimed at utilizing lowcost African palm fruit in the production of activated carbon and its application in removal of heavy metals in metal scrap effluents, and also utilize the availability of African palm fruit in the surrounding communities to solve environmental pollution.

\section{Materials and method}

\section{Activated carbon preparation}

African palm fruits were obtained at the Kawo main market, Kaduna North Local Government Area, Kaduna state, Nigeria. It was sun-dried for six consecutive days to dehydrate it completely. The sample was then pulverized using mortar and pestle and sieved using $63 \mu \mathrm{m}$ mesh sieve. The fine sample was then stored in an air tight container for subsequent work.

Activated carbon used as sorbent was prepared according to the protocol optimized by (Abdulrazak et al. 2015). Six grams (6 g) of ground African palm fruits were soaked in $50 \mathrm{ml}$ of $50 \% \mathrm{w} / \mathrm{v}$ phosphoric acid solution at $30{ }^{\circ} \mathrm{C}$ for 48-h. After filtration, the impregnated raw material was then carbonized in a muffle furnace at $300{ }^{\circ} \mathrm{C}$ for $2 \mathrm{~h}$ in nitrogen atmosphere. After cooling, each of the carbonized materials was washed with $200 \mathrm{ml}$ hot distilled water, and then dried for $2 \mathrm{~h}$ at $120{ }^{\circ} \mathrm{C}$. The dried activated carbon was then weighed to determine percentage yield, which is mathematically expressed as:

Percentage yield $(\%)=\frac{\text { yield }(\mathrm{g})}{\text { mass of raw material }(\mathrm{g})} \times 100$.

\section{Physiochemical properties}

\section{Bulk density}

A $25 \mathrm{~cm}^{3}$ cylinder was filled to the mark with the produced activated carbon. The cylinder was tapped for at least 12 min to compress the carbon to a steady volume. The compressed sample was poured out of the cylinder and 
weighed, and the mass (m) was divided by the final volume occupied in the cylinder:

Bulk density $=\frac{\text { mass }(\mathrm{g})}{\text { final volume }\left(\mathrm{cm}^{3}\right)}$.

\section{Conductivity}

A weight of $0.5 \mathrm{~g}$ of the activated carbon was placed into $100 \mathrm{~cm}^{3}$ beaker containing $50 \mathrm{~cm}^{3}$ distilled water. It was macerated using a glass rod and then allowed to stay for about $1 \mathrm{~h}$. The conductivity was determined using conductivity meter.

\section{Batch adsorption experiments}

\section{Effect of contact time}

A weight of $50 \mathrm{mg}$ of the produced activated carbon from African palm fruit was weighed and added to five different conical flasks containing $100 \mathrm{ml}$ of wastewater each in a $250 \mathrm{ml}$ beaker; the flasks were stirred at five agitations per minute. The first, second, third, fourth, and fifth beaker was agitated for 30, 60, 90, 120, and $150 \mathrm{~min}$, respectively. The content of each beaker was then filtered and prepared for the analysis.

After the treatment of the wastewater with the produced activated carbon the samples were filtered and the filtrates were analyzed with the aid of an Atomic Absorption Spectrophotometer at the Multi user Research Laboratory, Department of Chemistry, Ahmadu Bello University, Zaria, Nigeria. Data will be expressed as mean \pm standard deviation.

\section{Effect of temperature}

A weight of $50 \mathrm{mg}$ of the produced activated carbon from African palm fruit was weighed and put into a measured $100 \mathrm{ml}$ of the effluent wastewater in a $250 \mathrm{ml}$ beaker. The beaker together with its content is then placed on a rotating heating mantle. Both the heating mantle and the load were placed inside a fume cupboard. This procedure was repeated at $20,40,60,80$, and $100{ }^{\circ} \mathrm{C}$, respectively.

After the treatment of the waste water with the produced activated carbon, the samples were filtered and the filtrates were analyzed.

\section{Result and discussion}

Table 1 shows the physiochemical properties of the produced activated carbon. The bulk density and electrical conductivity of the activated carbon produced are presented below.
Table 2 shows the effect of contact time on removal of heavy metals; Copper, Nickel, Lead, and Cadmium. From the table below, there are higher treatment efficiencies at 60 min, except for Lead, which shows higher treatment efficiency at $90 \mathrm{~min}$. The result obtained is in agreement with similar work carried out by Abdulrazak et al. (2015), Srinivasan et al. (1998), and Ajmal et al. (1996). The organic contents of wastewater and the presence of microorganisms stimulate adsorption and, therefore, show that the produced activated carbon can improve performance by developing different bacterial species (Jeong et al. 2016), which may also played a part in the whole study. The initial concentration of heavy metals in the effluent sample used for the analysis is as follows: 1.82, 3.24, 2.62, and $1.52 \mathrm{mg} / \mathrm{g}$ of Cadmium, Nickel, Lead, and Copper, respectively.

From Table 2, the highest removal of Copper, Nickel, and Cadmium were the highest at an optimum contact time of $60 \mathrm{~min}$ after which the percentage removal decreases, while Lead removal was the highest at optimum contact time of $90 \mathrm{~min}$ after which the percentage removal decreases. Further shaking after the equilibrium time, only result in desorption (Anwar et al. 2010). This corresponds to the observation made by Elaigwu et al. (2009).

Table 3 shows the effect of temperature on removal of heavy metals: Copper, Nickel, Lead, and Cadmium. From the table, there is higher treatment efficiencies at a temperature of $80^{\circ} \mathrm{C}$ after which the percentage removal decreases.

Similar to the work of (Mataka et al. 2010) on lead removal from wastewater using Moringa oleifera seed, this study further shows that as the temperature of the experiment increases up until $80{ }^{\circ} \mathrm{C}$; there is a clear increase in the percentage of heavy metals removed from the effluent waste water samples after which the percentage removal tends to decrease.

From Table 3, the highest removal of Copper, Nickel, Lead, and Cadmium was at a temperature of $80{ }^{\circ} \mathrm{C}$ after which the percentage removal decreases. The result is in agreement with similar work carried out by (Abdulrazak et al. 2015), who reported higher adsorption properties of moringa oleifera pod on cadmium at higher temperature. The initial concentration of heavy metals in the effluent sample used for the analysis is as follows: 1.82, 3.24, 2.62, and $1.52 \mathrm{mg} / \mathrm{g}$ of Cadmium, Nickel, Lead, and Copper, respectively.

Table 1 Physiochemical properties of the produced activated carbon

\begin{tabular}{ll}
\hline Parameters & Values \\
\hline Bulk density $\left(\mathrm{g} / \mathrm{cm}^{3}\right)$ & 0.66 \\
Electrical conductivity $(\mu \mathrm{S} \mathrm{cm})$ & $1.2 \times 10^{2}$ \\
\hline
\end{tabular}


Table 2 Effect of contact time on removal of heavy metals

\begin{tabular}{lllll}
\hline Contact time (minutes) & \multicolumn{3}{l}{ Percentage removal of heavy metals $(\%)$} & \multicolumn{2}{l}{ Nickel } & Lead \\
\cline { 2 - 5 } & Cadmium & Copper & $85.76 \pm 0.127$ & $94.481 \pm 0.076$ \\
\hline 30 & $90.071 \pm 0.090$ & $94.934 \pm 0.181$ & $95.34 \pm 0.015$ & $97.750 \pm 0.166$ \\
60 & $99.235 \pm 0.148$ & $96.711 \pm 0.083$ & $91.21 \pm 0.010$ & $99.519 \pm 0.045$ \\
90 & $90.126 \pm 0.045$ & $95.579 \pm 0.059$ & $91.21 \pm 0.154$ & $93.664 \pm 0.104$ \\
120 & $90.071 \pm 0.063$ & $94.241 \pm 0.076$ & $89.79 \pm 0.048$ & $91.541 \pm 0.026$ \\
150 & $90.071 \pm 0.140$ & $92.724 \pm 0.017$ & & \\
\hline
\end{tabular}

Table 3 Effect of temperature on removal of heavy metals

\begin{tabular}{lllll}
\hline Temperature $\left({ }^{\circ} \mathrm{C}\right)$ & \multicolumn{3}{l}{ Percentage removal of heavy metals $(\%)$} & Nickel \\
\cline { 2 - 5 } & Cadmium & Copper & $80.13 \pm 0.023$ & Lead \\
\hline 20 & $88.16 \pm 0.156$ & $90.63 \pm 0.163$ & $83.70 \pm 0.005$ & $91.11 \pm 0.015$ \\
40 & $91.35 \pm 0.032$ & $94.59 \pm 0.131$ & $89.30 \pm 0.103$ & $93.48 \pm 0.020$ \\
60 & $91.66 \pm 0.026$ & $95.50 \pm 0.014$ & $92.01 \pm 0.018$ & $95.42 \pm 0.067$ \\
80 & $93.23 \pm 0.035$ & $96.71 \pm 0.097$ & $90.35 \pm 0.089$ & $93.79 \pm 0.122$ \\
100 & $91.53 \pm 0.185$ & $95.33 \pm 0.101$ & &
\end{tabular}

\section{Conclusion}

The activated carbon produced from African palm fruit, a low-cost agricultural product showed a significant ability in removing heavy metals: Cadmium, Copper, Nickel, and Lead from effluent wastewater from Old Panteka Market; a metal scrap Market located in Kaduna South Local Government Area, Kaduna State, Nigeria, and it, therefore, suggests that the availability of African palm fruit in the surrounding communities should be utilized in solving this environmental pollution.

Open Access This article is distributed under the terms of the Creative Commons Attribution 4.0 International License (http:// creativecommons.org/licenses/by/4.0/), which permits unrestricted use, distribution, and reproduction in any medium, provided you give appropriate credit to the original author(s) and the source, provide a link to the Creative Commons license, and indicate if changes were made.

\section{References}

Abdulrazak S, Sulyman YI, Bello HI, Akanni AS, Oniwapele YA, Muktari M (2015) Tannery wastewater treatment using activated carbon from Moringa oleifera pods. J Environ Sci Toxicol Food Technol 9(12):96-99

Ajmal M, Rao RAK, Siddiqui BA (1996) Studies on removal and recovery of $\mathrm{Cr}(\mathrm{VI})$ from electroplating wastes. Water Res 30(6):1478-1482

Anwar J, Shafique U, Waheed Z, Salman M, Dar A, Anwar S (2010) Removal of $\mathrm{Pb}(\mathrm{II})$ and $\mathrm{Cd}(\mathrm{II})$ from water by adsorption on peels of banana. Bioresour Technol 101(6):1752-1755
Bempah CK, Kwofie AB, Tutu AO, Danutsui D, Bentil N (2011) Assessing the potential dietary intake of heavy metals in some selected fruits and vegetables from Ghanaian markets. Elixir pollut 39(2011):4921-4926

Elaigwu SE, Usman LA, Awolola GV, Adebayo GB, Ajayi RMK (2009) Adsorption of $\mathrm{Pb}$ (II) from aqueous solution by activated carbon prepared from cow dung. Adv Nat Appl Sci 3(3):442-446

El-Said AG, Badaway NA, El Pasir AA (2010) Comparison of synthetic and natural adsorbents for sorption of $\mathrm{Ni}(\mathrm{II})$ ions from aqueous solution. J Nat Sci 8:86-94

Gupta VK, Mittal A, Krishnan L, Gabje V (2004) Adsorption kinetics and column operations for the removal and recovery of malachite green from wastewater using bottom ash. Purif Technol 40(1):87-96

Haware DJ, Pramod HP (2011) Determination of specific heavy metals in fruit juices using atomic absorption spectrophotometer. Int J Res Chem Environ 4(3):163-168

Jarup L (2003) Hazards of heavy metal contamination. Br Med Bull 2003(68):167-182

Jeong S, Kyungjin C, Hyokwan B, Torove L, Scott AR, Pejhman K, Saravanamuthu V (2016) Effect of microbial community structure on organic removal and biofouling in membrane adsorption bioreactor used in seawater pretreatment. Chem Eng J 294. doi:10.1016/j.cej.2016.02.108

Kadirvelu K, Thamaraiselvi K, Namasivayam C (2001) Removal of heavy metal from industrial wastewaters by adsorption onto activated carbon prepared from an agricultural solid waste. Bioresour Technol 76:63-65

Khan NA, Shaaban MG, Hassan MHA (2003) Removal of heavy metal using an inexpensive adsorbent. In: Proc. UM Research Seminar (2003) organized by Institute of Research Management \& Consultancy (IPPP), University of Malaya, Kuala Lumpur

Mataka LM, Sajidu SMI, Masamba RL, Mwatseteza JF (2010) Cadmium sorption by Moringa stenopetala and Moringa oleifera seed powders: batch, time, temperature, $\mathrm{pH}$ and adsorption isotherm studies. Int J Water Resour Environ Eng 2(3):50-59 
Mohan D, Singh KP (2002) Single and multi component adsorption of cadmuim and zinc using activated carbon derived from bagasseAn agricultural waste. Water Res 36(9):2304-2318

Nwabanne JT, Igbokwe PK (2012) Comparative study of Lead (II) removal from aqueous solution using different adsorbents. Int $\mathbf{J}$ Eng Res Appl 2:18301838

Nwankwo JN, Elinder CG (1979) Cadmium Zinc and Lead concentrations in soils and in foods grown near a Zinc and Lead smelter in Zambia. Bull Environ Contam Toxicol 22:625-631

Prabakarani R, Arivoli S, Hema M, Kamatchi C (2011) Removal of $\mathrm{Cu}(\mathrm{II})$ ion from aqueous solution by low cost activated carbon from thespesia populnea bark. J Chem Pharm Res 3:532-543

Selvi K, Pattabhi S, Kadirvelu K (2001) Removal of Cr(VI) from aqueous solution by adsorption onto activated carbon. Bioresour Technol 80:87-89

Srinivasan K, Balasubramaniam N, Ramakrishna TV (1998) Studies on chromium removal by rice husk carbon. Indian $\mathrm{J}$ Environ Health 30(4):376-387
Srivastava S, Goyal P (2010) Novel biomaterials: decontamination of toxic metals from wastewater. Springer, NY

Sulyman YI, Abdulrazak S, Oniwapele YA, Amad A (2015) Concentration of heavy metals in some selected cereals sourced within Kaduna state, Nigeria. J Environ Sci Toxicol Food Technol 9(10):17-19

Tan WT, Ooi ST, Lee CK (1993) Removal of Chromium (VI) from solution by coconut husk and palm pressed fibre. Environ Technol 14:277-282

Verla AW, Horsfall M, Verla EN, Spiff AI, Ekpete OA (2012) Preparation and characterization of activated carbon from fluted pumpkin seed shell. Asian J Nat Appl Sci 1:39-50

WHO (2006) WHO guidelines for the safe use of wastewater, excreta and greywater volume IV: excreta and greywater use in agriculture. World Health Organization (WHO), Geneva

Wong KK, Lee CK, Low KS, Haron MJ (2003) Removal of $\mathrm{Cu}$ and $\mathrm{Pb}$ by tartaric acid modified rice husk from wastewater. J Environ Sci Health 30(2):241-261 